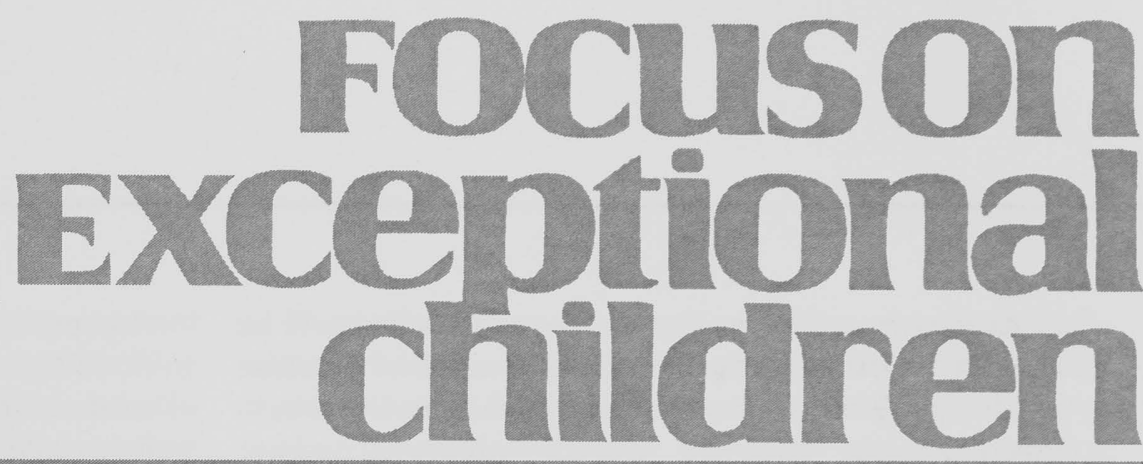

\title{
Promoting Special Education Preservice Teacher Expertise
}

\author{
Melinda M. Leko, Mary T. Brownell, Paul T. Sindelar, and Kristin Murphy
}

Teacher education has been criticized as an ineffective enterprise that discourages talented individuals from choosing careers in education (Hess, 2001; Walsh, 2001). Opponents of teacher education argue that lengthy program requirements are prohibitive in terms of cost and time and ultimately unnecessary given that some research has pointed to the importance of teachers' subject matter knowledge (Hess, 2001; Walsh, 2001). In essence, individuals like Hess and Walsh contend that the gate-keeping mechanism for entry into the teaching profession should be an individual's knowledge of particular subject matter and not the completion of a teacher preparation program. Despite these criticisms, several studies of special education teacher education have demonstrated the benefits of extensive preparation (Boe, Cook, \& Sunderland, 2008; Feng \& Sass, 2011; Nougaret, Scruggs, \& Mastropieri, 2005; Sindelar, Daunic, \& Rennells, 2004).

These benefits apply to several dimensions of teacher quality, including instructional planning, classroom practice, retention, and student achievement. Boe and his colleagues, using large-scale databases like the Schools and Staffing Survey (SASS) and the Teacher Follow-Up Survey (TFS), have determined that extensive preparation mitigates special education teacher attrition (Boe et al., 2008; Boe, Shin, \& Cook, 2007). Feng and Sass (2011) also used large datasets to better understand the impact of special education preparation on student achievement. Chief among their findings was that students in special education reading classes whose teachers had completed preservice preparation made greater achievement gains than students whose teachers had not.

Two studies examined the effect of extensive special education preparation on teachers' planning and classroom practice. Nougaret et al. (2005) compared novice teachers with little or no preparation to novices who had completed preservice training. Sindelar et al. (2004) compared the classroom performance of novice special education teachers who had completed traditional or alternative routes. In both studies the research teams found that teachers who completed traditional preparation programs outperformed teachers in the comparison groups. Such findings have corroborated what most special education teacher education scholars have known intuitively for some time-providing prospective special educators with high-quality training is necessary and worthy work. Yet, what constitutes high-quality teacher education for special education?

Dr. Leko is an assistant professor in the Department of Rehabilitation Psychology and Special Education at the University of Wisconsin-Madison, Dr. Brownell is a professor, Dr. Sindelar is a professor, and Ms. Murphy is a doctoral candidate in the School of Special Education, School Psychology and Early Childhood Studies at the University of Florida. 
At minimum, high-quality teacher education should be based on a clear understanding of what constitutes expertise in other professions and some assumptions about how such expertise can be developed. In special education, we have only a small number of studies attempting to articulate the dimensions of teacher expertise in special education (Bishop, Brownell, Klingner, Leko, \& Galman, 2010; Brownell et al., 2007; Brownell et al., 2009; Carlson, Lee, \& Schroll, 2004; Feng \& Sass, 2011; Griffin, Jitendra, \& League, 2009; Seo, Brownell, Bishop, \& Dingle, 2008; Stough \& Palmer, 2003). Though the number of studies is limited and their findings are tentative, results suggest that special education teacher quality is defined by (a) extended preparation in special education; (b) knowledge for teaching both elementary mathematics and reading; (c) ability to apply knowledge to practice, though beginning special education teachers seem less able to apply their knowledge; (d) explicit, interactive instruction to promote student achievement; (e) high levels of student engagement during instruction; (f) effective classroom management; (g) a sense of

\section{Focuson
Exceptional
children}

ISSN $0015-511 \mathrm{X}$

FOCUS ON EXCEPTIONAL CHILDREN (USPS 203-360) is published monthly except June, July, and August as a service to teachers, special educators, curriculum specialists, administrators, and those concerned with the special education of exceptional children. This publication is annotated and indexed by the ERIC Clearinghouse on Handicapped and Gifted Children for publication in the monthly Current Index to Journals in Education (CIJE) and the quarterly index, Exceptional Children Education Resources (ECER). The full text of Focus on Exceptional Children is also available in the electronic versions of the Education Index. It is also available in microfilm from Serials Acquisitions, National Archive Publishing Company, P.O. Box 998, Ann Arbor, MI 48106-0998. Subscription rates: individual, $\$ 50$ per year; institutions, \$68 per year. Copyright (C) 2012, Love Publishing Company. All rights reserved. Reproduction in whole or part without written permission is prohibited. Printed in the United States of America. Periodical postage is paid at Denver, Colorado. POSTMASTER: Send address changes to:

Love Publishing Company

Executive and Editorial Office P.O. Box 22353

Denver, Colorado 80222

Telephone (303) 221-7333

\section{CONSULTING EDITORS}

Steve Graham Vanderbilt University
Ron Nelson

University of Nebraska-Lincoln

Eva Horn

University of Kansas

Carrie E. Watterson

Senior Editor
Stanley F. Love

Publisher responsibility for the learning of students with disabilities; (h) ability to consider the individual learning and behavioral needs of students with disabilities during instruction; (j) a motivation to improve instruction; and (i) a sense of teaching efficacy.

These studies provide some direction for determining what we are trying to accomplish in special education teacher education. It is in light of these dimensions of expertise that we examined the last decade of special education teacher education research. We selected the last decade of research because the changing policy context has put teacher quality and strategies for preparing quality teachers under the microscope. We expected to see an increase in the number of studies focused on special education teacher education and improvement in the quality of those studies. We asked these guiding questions: What domains of special education teacher expertise (e.g., literacy, classroom management) was teacher education research addressing? Was knowledge being presented in ways that enabled beginning special education teachers' opportunities to apply it? In other words, did certain pedagogical practices seem to be particularly promising for helping beginning special education teachers apply their knowledge? Were preservice teacher beliefs being addressed in ways that would impact beginning special education teachers once they entered the classroom? Further, what types of programs were most likely to support beginning special education teachers in their learning?

\section{METHOD FOR THE REVIEW}

To find answers to our questions, we searched the following journals for research articles published from 2000 to 2011: Action in Teacher Education, Behavioral Disorders, Education and Treatment of Children, Exceptional Children, Exceptionality, Journal of Special Education, Journal of Special Education Technology, Journal of Teacher Education, Journal of Technology and Teacher Education, Learning Disabilities Quarterly, Remedial and Special Education, Teaching and Teacher Education, Teacher Education Quarterly, and Teacher Education and Special Education. In total, we found 93 studies that met our criteria, a number that has increased exponentially since two previous reviews of special education teacher education research (Sindelar, Bishop, \& Brownell, 2006; Tulbert, Sindelar, Correa, \& La Porte, 1996).

\section{RESULTS}

We discovered that although the number of studies about special education teacher preparation has increased, they are scattered in focus and uneven in quality, thus making it difficult to draw definitive conclusions about how high-quality 
special education teacher training should be conceptualized and implemented. However, there do seem to be promising approaches for fostering preservice special education teachers' knowledge of facts, concepts, and principles and their ability to apply that knowledge. Plus, with increased emphasis placed on reading and mathematics, we noticed that teacher education researchers had begun to take seriously the charge for educating special education preservice teachers about the pedagogical content knowledge they would need to be successful. Additionally, certain pedagogical practices appear to develop preservice teachers' mindsets and beliefs in ways that allow for more supportive views of students with disabilities and better integration of conceptual and practical knowledge. Finally, certain program features seem to promote special education preservice teachers' development more than others. In the following sections, we provide examples of promising practices in each of these areas in response to the guiding questions we posed earlier.

\section{WHAT DOMAINS OF SPECIAL EDUCATION TEACHER EXPERTISE IS TEACHER EDUCATION RESEARCH ADDRESSING?}

The field of special education's longtime focus on evidence-based practice has shaped much of teacher preparation in special education. Many universities offer special education coursework that focuses on (a) descriptions of these evidence-based practices and their use in the classroom, (b) knowledge of students with disabilities and their learning and behavioral needs, and (c) effective inclusive practices (Brownell, Sindelar, Kiely, \& Danielson, 2010). Courses like Curriculum and Assessment and Methods for Students with Mild to Moderate Disabilities, Introduction to Exceptional Children and Youth, and Inclusive Schooling are commonplace in many university programs, and, until the last decade, the idea of content instruction in special education has been absent from many special education teacher education programs. Thus, many of the studies we read examined teacher education practices designed to provide preservice teachers with knowledge of effective inclusion practices, students with disabilities and their educational needs, assistive technology, evidence-based practices, and behavior management. We found, however, that a growing number of research studies investigated preservice teachers' content knowledge and requisite procedural knowledge for teaching this content - expertise commonly referred to as pedagogical content knowledge. The emergence of this research is probably related to recognition in our field that content knowledge is likely an important component of teacher effectiveness in special education (Brownell et al., 2010; Moats, 2009). Also we found several studies focused on knowledge and skills necessary for effective collaboration.
Thus, although special education teacher education's traditional focus on general pedagogical practices for educating students with disabilities still permeates the literature, we saw pedagogical content knowledge and collaboration emerge as critical areas of domain expertise for today's special educator. We discuss promising practices in each of these areas in the following sections.

\section{Pedagogical Content Knowledge}

In our review, several studies of reading and mathematics revealed teacher educator approaches to integrating how to teach content with the procedural knowledge necessary for implementing instruction and knowledge of student performance (Alexander, Lignugaris-Kraft, \& Forbush, 2007; Paulsen, 2005; Spear-Swerling, 2009; Spear-Swerling \& Brucker, 2004). Mostly, these approaches involved contentfocused methods coursework combined with highly structured field experiences. As an example, Alexander, LinugarisKraft, and Forbush studied a carefully constructed course and field experience designed to help students learn to use direct instruction and assessment strategies taught previously in a beginning course for teaching mathematics content. In the mathematics course, students analyzed the National Council of Teachers of Mathematics standards and developed skill sequences to be used in curriculum-based assessments (CBAs) that could be applied to hypothetical and real students. Preservice teachers were then presented with case studies for the purpose of learning how to apply a direct instruction sequence that incorporated the use of CBA. Instructors used principles of direct instruction to support preservice teacher learning with two case studies. After practice with the two cases, preservice teachers analyzed a third case independently and were provided with corrective feedback. Once the course concluded, preservice teachers were expected to apply what they had learned about instruction and assessment in a practicum. Field supervisors trained in an observation protocol visited classrooms three to five times to observe instruction and provide preservice teachers with feedback. Preservice teachers demonstrated gains in knowledge and an ability to apply direct instruction practices to classrooms. Additionally, preservice teachers' students improved on concepts and skills taught, as demonstrated in the CBAs collected.

Similarly, in the area of reading, researchers have demonstrated that carefully designed coursework accompanied by structured field experiences enabled preservice teachers, both those with and without prior teaching experience, to grow in their content knowledge for teaching reading and in their ability to promote student reading achievement (SpearSwerling, 2009; Spear-Swerling \& Brucker, 2004). In these studies, preservice special education teachers enrolled in a language arts course in which they learned about reading 
development, struggles that students encounter, English word structure, phonics, and reading assessments. In addition to the course, they had to tutor a second grader in basic reading and spelling skills. After 7 weeks of coursework, they begin tutoring for an hour once a week. Preservice teachers used a lesson plan format to guide their planning and the amount of time they devoted to specific instructional activities. The course instructor supervised all tutoring sessions and was available to model various techniques, provide suggestions, and provide corrective feedback to preservice teachers. Preservice teachers' gains in knowledge and students' gains on letter sound knowledge as well as reading and spelling of irregular words and phonics concepts were assessed.

Another study focused on reading showed that a wellstructured tutoring experience in the schools could increase preservice teachers' knowledge about phonics and English word structure (Al Otaiba, Schatschneider, \& Silverman, 2005). Preservice teachers participating in the tutoring experience had taken a language arts methods course and participated in two practicum experiences. After completing the tutoring experience, preservice teachers had grown in their knowledge, rather substantially, and they were able to affect positively the achievement of their students. In addition to these accomplishments, the preservice students demonstrated a stronger capacity for examining the needs of individual children, which suggested that they were integrating their knowledge for teaching content with knowledge of their students.

\section{Collaboration}

Collaboration with general education teachers and parents is a mainstay of special education practice, and the research in special education teacher education reinforces the important role that collaboration is assumed to play in improving instruction for students with disabilities. Several strategies have been used to develop the collaborative skills of special and general education preservice teachers, including placing general and special education preservice teachers in collaborative teaching situations, making collaboration an integral part of coursework, and training preservice teachers in particular collaborative skills. The approaches that seemed to hold the most potential were those that taught collaborative skills or a structure for working together.

For example, Richards, Hunley, Weaver, and Landers (2003) examined a teacher education program designed to teach collaborative skills to general and special education teachers. Both secondary and special education preservice students were involved in three university-based activities: (a) training in a collaborative problem-solving process, (b) disability simulation activities that were planned and implemented by the special education preservice teachers, and (c) training in data collection. After completing the university-based activities, two secondary preservice teachers were teamed with a special education preservice teacher in a field placement. Each week they attended a seminar where they were trained in instructional and curriculum adaptations; they also discussed these adaptations as they related to specific students. Secondary preservice students participated in an additional field experience with cooperating teachers in their content area; they were instructed to employ a collaborative problem-solving process to generate an appropriate intervention or accommodation for the student. Richards et al. assessed the impact of the course activities and field experience using open-ended questions. At the end of the project, preservice students also responded to a survey asking them to rate the effectiveness of different collaboration experiences. Both special and secondary preservice teachers rated the series of collaboration experiences highly.

Only one study attempted to document the ways in which preservice teachers changed as a result of concrete opportunities to learn a collaborative skill. Bradley and Monda-Amaya (2005) used vignettes to teach special education preservice teachers how to understand and analyze conflict situations. Role plays were then used to resolve the conflicts. A multiple baseline design was used to evaluate the effectiveness of the conflict resolution training package. In baseline and treatment conditions, preservice teachers were asked to analyze vignettes for the purpose of determining what was happening and provide steps towards resolving the conflict. Generalization probes were also collected. Analysis of probe data indicated that preservice teachers' performance was comparable to that of experts.

\section{Summary on Domain Expertise}

In our review, collaboration and pedagogical content knowledge in reading and mathematics were the prominently researched areas of domain expertise for prospective special educators. Content methods coursework combined with field experiences shows that teachers can develop knowledge of how to teach content and integrate that knowledge into classroom instruction in ways that improve the achievement of students with disabilities. Research also provides some evidence that teacher educators see collaborative skills as beneficial to learn and that special education preservice teachers can at least acquire knowledge of these skills and apply them through vignettes. What special education teachers will do with the knowledge and skill they have acquired in reading, mathematics, and collaboration upon entering the classroom remains to be seen. Next we provide a more thorough discussion of the pedagogical approaches (i.e., case-based instruction and field experiences) that were introduced in this section. 


\section{WHAT PEDAGOGICAL APPROACHES FACILITATE PRESERVICE TEACHERS' KNOWLEDGE APPLICATION?}

It is well established in the expert literature that competence in any field depends on a well-integrated knowledge base that can be applied in problem-solving situations. Thus, we were encouraged by the number of studies that examined pedagogies that facilitate higher levels of learning by preservice teachers-requiring them to not only demonstrate knowledge acquisition but also application. Prominent among these pedagogies were the use of video modeling, case-based instruction, and field experiences.

\section{Video Modeling}

Technology, particularly the use of video modeling, seems to be one way of helping prospective teachers acquire and apply knowledge. Van Laarhooven et al. (2008) reported on the development of a video tutorial on the use of various assistive technologies (AT). The tutorials included video demonstrations on the purpose and correct use of software and devices that help individuals with difficulties in writing, math, reading, communication, or physical control of their environment. These tutorials were incorporated into a series of courses in which preservice teachers were asked to complete the web-based tutorials and then complete a survey on their perceptions of AT and the tutorials. After completing the video tutorials, preservice teachers indicated high levels of familiarity of different AT and comfort using them.

Video models have also been used successfully in helping preservice teachers acquire and apply knowledge in various content areas. Dieker et al. (2009) showed how video models of effective practice in reading, mathematics, and science could be used to develop teachers' procedural knowledge for teaching content-focused strategies. This study involved preservice teachers participating in coursework at three different universities. Video cases were presented that showed a teacher demonstrating Text Talk, a vocabulary strategy, dynamic assessment techniques for evaluating students' understanding of mathematics, and the 5E Learning Cycle, a method for directed inquiry in science. Preservice teachers in all three conditions (i.e., reading, mathematics, and science) were surveyed prior to and after viewing the videos. In each case, after viewing the videos, these teachers were able to describe more of the steps involved in implementing the demonstrated practice compared to their descriptions provided prior to viewing videos.

Gormley and Ruhl (2007) combined the use of a video tutorial and online study guide to help preservice teachers acquire knowledge of individual phonemes and their orthographic representations plus how to pronounce the sounds correctly. Additionally, they were interested in seeing whether preservice teachers could use their knowledge to identify miscues that students made when reading aloud. Preservice teachers participating in the intervention were better able to hear sounds and represent them orthographically than those who did not receive the intervention. They were also able to generalize their knowledge to an irregular word-identification task where they had to identify irregular versus regular words, and control group preservice teachers were not. Treatment teachers were not, however, more able to apply their knowledge to analyze a child's errors when reading. These findings suggest that video models might be useful for building the content or procedural knowledge needed for teaching a subject but that they may not be sufficient for developing the more integrated knowledge needed for teaching.

\section{Case Studies}

The case study method, or case-based instruction, refers to the use of practically based narratives that represent authentic situations and problems of practice. This type of pedagogy has been shown previously in a review of effective special education teacher preparation practices to hold some promise for improving preservice teacher learning (Sindelar et al., 2006), because it facilitates application of course knowledge into practice even when preservice teachers do not have opportunities to work in real classroom settings. Also, preservice teachers can practice newly acquired skills in a safe environment where potential mistakes will not have negative consequences for teachers and students in real classrooms. Typically, preservice teachers are presented with a narrative about a fictitious student or classroom situation and then required to answer questions about the case. The questions usually require students to apply course knowledge as opposed to demonstrating basic acquisition. For example, students might be asked to describe how they would respond to a particular situation described in the case in relation to course content. We found five studies that used case-based instruction with special education preservice teachers.

Kim, Utke, and Hupp (2005), for example, used case studies of special educators working with students with multiple disabilities as the basis for small group discussion. Accompanying each case study were three discussion questions that asked preservice teachers to devise assessment and instructional strategies for students with sensory impairments. The researchers compared the incorporation of the case studies to discussion groups that were given application questions without an accompanying case study. Results indicated that both groups (i.e., case study vs. application questions only) performed similarly on midterm assessments and were equally satisfied with the two types of discussion. The application question group, however, scored higher on ratings of their group discussion summaries. The findings of this study suggest that case studies may not be any more 
effective in fostering group discussion than application questions alone. However, case-based instruction does seem to be effective at helping students apply course knowledge. The authors concluded that one possible reason for the differences between the groups was that the case studies were not complex enough and did not truly mirror authentic classroom situations, in which a myriad of factors are at work.

Mitchem et al. (2009) further explored how different case study implementations influenced preservice teachers' learning about planning, instruction, intervention, and assessment of students with social, emotional, and behavioral disorders. The researchers learned that the use of case studies leads to significant learning outcomes, as measured by differences in number of facts and concepts represented on a pre- and posttest concept map as well as the number of linkages made between these facts and concepts, but only when cases were extensively incorporated into course assignments and application activities. In these instances, preservice teachers were required to complete embedded case study activities or demonstrate an ability to transfer knowledge acquired from the case to novel situations. When preservice teachers were presented with cases merely as a resource for contextualizing course assignments (i.e., preservice teachers were not required to complete any embedded case study assignments) learning outcomes were not significant.

\section{Field Experiences}

The use of field experiences is considered to be an important mechanism for providing preservice teachers with opportunities to apply knowledge in practical teaching situations.

As discussed previously, researchers have begun to demonstrate the effectiveness of pairing coursework and field experiences to build teachers' pedagogical content knowledge.

\section{Aligning Coursework and Training Experiences with Field Experiences}

Field experiences that were carefully designed to facilitate preservice teachers' implementation of strategies acquired during their coursework seemed to have the most promise for increasing preservice teachers' sense of efficacy, perceptions of competence, planning abilities, knowledge, and classroom performance. Within these carefully structured courses and field experiences, many strategies were used to help preservice teachers develop applied knowledge. Case studies, simulations, faculty modeling of technology, applied assignments, collaborative teaching arrangements, and structured coursework or training experiences integrated with field experiences were used to help preservice teachers develop knowledge of how certain strategies and innovations could be used in the classroom.

Maheady, Jabot, Rey, and Michielli-Pendl (2007) assessed the impact of a structured course combined with a field experience on preservice teachers' use of evidence-based practices in their lesson plans and gains in student achievement as measured through teacher-created assessments. The course and field experience studied were offered to education majors in their freshman year and provided introductory information about being a teacher and schooling. Preservice teachers were taught about major educational theories and evidence-based practices based on those theories and then expected to implement these practices at least once a week in a 4-hour practicum that extended over 8 weeks. During the practicum, preservice teachers were required to collect student evidence in a particular area and chose an evidencebased practice that addressed identified student needs. They had six practices to choose from that had been modeled previously in their class; they were also provided with the assessments to use. After selecting a practice, they developed a lesson plan for implementing it. Student gains on teachermade pre- and posttests along with analyses of lesson plans and observations of the lesson plan being implemented were conducted to determine the efficacy of this approach. Analyses of the observation data showed that preservice teachers implemented evidence-based practices with a high degree of accuracy, between .84 to .96 , and the students of these preservice teachers made strong pre- to posttest gains.

Instead of using coursework to develop strategy knowledge, Gettinger, Stoiber, and Koscik (2008) used extended workshops combined with field experiences to develop preservice teachers' knowledge about challenging behaviors and to engage in interdisciplinary teaming for the purpose of conducting and interpreting functional behavior assessments and implementing positive behavioral supports in classroom settings. Preservice teachers attended a two-phase training session that combined workshop experiences with field experiences. In Phase I, preservice teachers participated in 3-hour weekly training sessions where they read about topics being covered, analyzed hypothetical cases, and reviewed guidelines for field-based activities. After 2 weeks, preservice teachers participated in intensive field experiences in which they were coached to implement strategies taught in the workshop. In Phase II, preservice teachers prepared case reports for target children from Phase I. Preservice teachers participating in the training were compared to nontreatment preservice teachers from the same teacher education program on five measures: (a) knowledge of training content, (b) skill self-ratings, (c) a consultation simulation task, (d) a self-efficacy measure, and (e) goal attainment for target students. Teachers provided behavioral consultation by the preservice teachers also rated their competence. Participants outperformed comparison teachers on all measures but the self-efficacy measures.

In Project Accept (Van Laarhoven, Munk, Lynch, Bosma, $\&$ Rouse, 2007), a collaborative teacher education program, 
a collaborative teaching seminar was combined with an institute, enhanced instruction in target areas, and field placements structured to provide preservice elementary and special education majors with knowledge and skills for using functional behavioral assessment (FBA), instructional accommodations, and AT to provide inclusive instruction. Simulation activities and team-building activities were used to prepare students for a final 6-hour field experience where they were expected to coteach a lesson. In two separate analyses of Project Accept, Van Laarhoven et al. (2007) found that Project Accept participants, compared to nonparticipating peers at the same university, had more positive attitudes toward inclusion and were better able to respond to questions about classroom vignettes. Additionally, 91\% of Project Accept participants were rated positively on their cotaught lesson by trained project staff. Finally, project participants and comparison teachers were followed into their 1 st year of teaching and asked to complete a survey focused on their sense of preparedness for certain aspects of their job; Project Accept participants rated their experiences somewhat more positively than novice teachers in the comparison group.

\section{Ensuring Access to High-Quality Field Experiences}

To ensure that preservice special education students have opportunities to apply their knowledge, access to high-quality field experiences is essential. Leko and Brownell (2011), for example, showed that when preservice special education teachers had opportunities to apply knowledge they were acquiring about teaching reading in their preservice programs, they were able to improve in the quality of their reading instruction. However, when these opportunities were lacking, they struggled to figure out how they could apply the concepts acquired in coursework about effective reading instruction and sometimes even questioned their value (Leko \& Brownell, 2011). Thus, researched aimed at developing effective strategies for improving the quality of field experiences is imperative.

Only two studies described strategies or approaches they used to either ensure or improve the quality of cooperating teachers to make their expertise more accessible to preservice special education teachers. At California State University at Northridge, cooperating teachers were professional models who were carefully selected after classroom observations and recommendations from program faculty (Sears, Cavallaro, \& Hall, 2004). Preservice special education teachers were placed in their classrooms 6 hours a week for practicum experiences occurring in the first and second semester of their program. Both the collaborating teacher and university supervisor provided feedback to preservice teachers on competencies developed for each early field experience. Analysis of the observations suggested that first- and second-semester students were performing at or above expectations. Additionally, the initial two experiences seemed effective in encouraging preservice teachers who were not suitable for special education to pursue other options.

Parker-Katz and Hughes (2008) sought to improve special education teachers' abilities to mentor preservice special education teachers. Fifteen mentors who worked with diverse students and were recommended by fellow teachers, administrators, and education faculty were chosen. These mentors were assigned one to three preservice students to support throughout their preparation programs. Mentors participated in 8 hours of professional development designed to guide them in selecting literacy artifacts (i.e., a work sample that can be used to demonstrate teaching and learning literacy in a special education classroom), developing an understanding of how to work with adult learners, and learning how to lead collaborative learning conversations with their preservice teachers. Mentor record and reflection forms revealed that mentors selected artifacts mostly to demonstrate how mentees modified instruction for learners. Mentors also saw themselves as successful in leading discussions with mentees about the artifacts and helping them learn, a perception they based on preservice teachers' reactions and comments. In addition, mentors were able to be self-critical of literacy artifacts and described ways they adjusted their discussions to be more effective. Feedback through surveys indicated that preservice teachers found the discussions helpful and gained ideas of how students acquired literacy.

Another strategy for ensuring that field experiences are productive is performance-based feedback. Three studies have shown that when special education preservice teachers receive immediate, positive, and corrective feedback on their performance via technology, it positively influences their attitudes and classroom performance (Rock et al., 2009; Scheeler \& Lee, 2002; Scheeler, McAfee, Ruhl, \& Lee, 2006). As an example, Rock and her colleagues (2009) used bug in the ear technology (BIE) that relied on an internet video technology (Skype) and a Bluetooth mobile device to provide preservice special education teachers with realtime feedback during reading instruction. First, the researchers taught preservice teachers how to use high-access instructional strategies, such as choral and nonverbal response, partner strategies, and cloze reading. Then the researchers scheduled follow-up observations with BIE. At the end of the study, preservice teachers reported that the BIE technology was helpful even though it made them anxious initially. Preservice teachers significantly increased their use of high-access instructional strategies, partner strategies, and cloze reading strategies, while they significantly reduced their use of low-access instructional strategies (e.g., hand raising and waiting to be called on, round robin reading). Additionally, these teachers significantly increased their use of positive praise statements during 
instruction but did not reduce the number of redirects or reprimands. Finally, the students of these preservice teachers demonstrated significant gains in on-task behavior and academic engagement after BIE was implemented.

\section{Summary on Pedagogical Practices}

Research on video modeling and case-based instruction demonstrates that these approaches can affect teacher beliefs and learning, at least as demonstrated on assessments typical of university coursework (e.g., course tests, papers addressing a particular video or case); however, there are some cautions. One, we need more research-based information about the efficacy of such approaches for aiding teachers' knowledge application in classroom settings and the conditions under which such instruction can be employed effectively to draw any definitive conclusions about this approach. The Alexander et al. (2007) study discussed in the section on pedagogical content knowledge was one of the few in which researchers used case-based instruction and then followed preservice teachers into a practicum placement. Two, to implement case-based approaches effectively takes a good deal of time and planning; faculty often find cases difficult and time consuming to create (Elksnin, 1998). Thus, it might be helpful if faculty had more access to carefully designed cases.

An approach that seems particularly effective in helping preservice teachers apply their knowledge is the pairing of coursework with related field experiences. It seems that, when concrete strategies are taught through coursework and then implemented in carefully structured field experiences, preservice special and general education teachers improve their knowledge of, confidence in, and use of inclusive and evidence-based practices in classrooms. The content area research we described earlier supports this finding. The alignment of methods coursework with content-specific field experiences provides a powerful context for preservice teachers to acquire content knowledge, knowledge of how to teach the content, and ways to integrate that knowledge into classroom instruction to improve the achievement of students with disabilities. An important caveat is that the quality of the field experience cannot be ignored if teacher educators hope to capitalize on this type of pedagogy. Findings from ParkerKatz and Hughes (2008) and Sears et al. (2004) highlight the need to select mentors carefully and determine ways to foster their development. Bug in the ear technology is emerging as a promising way of improving preservice students' field experiences. If preservice special education teachers are expected to situate their knowledge successfully in classroom settings, then their opportunities to enact knowledge must be maximized. How gains in knowledge and skill transfer to classroom instruction in the 1st year of teaching or different instructional settings, however, is not understood.

\section{ARE BELIEFS ADDRESSED IN WAYS THAT IMPACT BEGINNING SPECIAL EDUCATION TEACHERS ONCE THEY ENTER THE CLASSROOM?}

Helping preservice teachers adopt beliefs and attitudes that support effective teaching practices for students with disabilities has been an important and highly emphasized area of special education teacher education. Much of the literature in this area consisted of teacher educators attempting to examine or change preservice teachers' beliefs in the context of a single course or courses where preservice teachers participated in interactive learning activities designed to foster positive beliefs about teaching practices or students with disabilities and those who are culturally and linguistically diverse.

Dotger and Ashby (2010) examined preservice teachers' philosophies about inclusive education through the use of simulated interactions. Preservice teachers met with paraprofessionals who were trained to interact with the preservice teachers in ways that would encourage them to reflect on their beliefs regarding inclusionary practices for students with disabilities. The use of simulated interactions allowed the researchers and teacher educators to better understand the degree to which preservice teachers were able to articulate and draw on their beliefs when placed in a context that required communication and planning with paraprofessionals.

In addition to fostering positive perceptions of individuals with disabilities, studies have also investigated preservice teacher beliefs about prominent instructional practices for students with disabilities. Allinder (2001) modeled a series of evidence-based practices including classwide peer tutoring (CWPT) and curriculum-based measurement (CBM) in an introductory special education course. At the end of the semester, the preservice teachers rated the practices that had been modeled in class as more useful than practices that had not been modeled in class. Also, Allinder found that preservice teachers rated highly experience-based learning opportunities such as volunteering with individuals with disabilities in community organizations and programs. Preservice teachers' perceptions of collaboration and coteaching were also studied in the literature we found. In a case study, Kamens (2007) studied the experiences of two pairs of preservice teachers who cotaught during their studentteaching experience. Data from interviews with preservice teachers and cooperating teachers, preservice teacher journals, and observation reports indicated that the preservice teachers learned that personalities have an impact on the coteaching relationship as does the structure of classroom interactions, which had to be continually reviewed and negotiated. In general, the preservice teachers valued the peer support they received as being part of a collaborative team, and they felt that students benefitted from the coteaching model. 
Two other groups of researchers examined the role that a course combined with active learning opportunities, such as cases, videos, self-analysis activities, and dialogue journals played in changing special and general education preservice teachers' understandings of culturally and linguistically diverse students and their families. Preservice teachers participating in these studies were graduate students from special and general education programs as well as undergraduates from a unified early childhood program (Correa, Hudson, \& Hayes, 2004; Trent \& Dixon, 2004). In both cases, preservice teachers demonstrated deeper knowledge and more complex understandings of culturally and linguistically diverse students, as demonstrated by their performance on pre- and post-concept maps combined with essays explaining maps.

In a follow-up study of teacher education graduates, Daunic, Correa, and Reyes-Blanes (2004) studied general and special education 1st-year teachers who graduated from teacher preparation programs in Florida to determine whether stronger preparation in culturally and linguistically diverse coursework and field experiences transferred to instructional practices. Teachers were rated according to the amount of coursework and field work they reported having on teaching culturally and linguistically diverse students. Teachers' classroom practice was scored using the PRAXIS III observation system and submitted to a two-way multivariate analysis of variance analyzing main effect differences for teachers in the low/no versus high preparation groups and special education versus general education teachers. Researchers found no differences in Praxis ratings based on participants' CLD preparation. However, they did observe significant differences between general education and special education teachers. Special education teachers were rated higher on gaining familiarity with students' background knowledge and engaging in equitable interactions with all students; general education teachers were rated higher on encouraging students to extend their thinking.

\section{Summary on Beliefs}

It seems that coursework and active learning opportunities can change general and special education teachers' understandings about disability and cultural and linguistic diversity; however, the degree to which those understandings result in action on the part of new teachers has not been established. A few of the studies we reviewed examined attempts to influence preservice teachers' beliefs and understandings in relation to their practice during coursework or student teaching, but this handful of studies does not help us understand the impact of such teacher education efforts on preservice teachers' future practice. Clearly, there are still many unanswered questions about how to address beliefs in ways that will impact beginning special and general education teachers working with a diverse population of students with disabilities once they graduate and enter the classroom.

\section{WHAT TYPES OF PROGRAMS MOST LIKELY SUPPORT BEGINNING SPECIAL EDUCATION TEACHER LEARNING?}

Novice teachers have great potential for professional growth, particularly in their 1st or 2 nd year of practice. In this section, we consider the contribution that initial preparation makes to subsequent professional development. In special education, several types of programs have been studied extensively, and we review those types here. Some are broadly cast, as in traditional versus alternative route preparation or extensive versus less extensive preparation. Among the more focused program types, we consider unified preparation in $\mathrm{K}-12$ and in early childhood and the use of distance education delivery mechanisms.

\section{Traditional and Alternative Route Preparation}

Rosenberg and Sindelar (2005) reviewed 10 studies of alternative route preparation in special education. Most of these studies were program evaluations, but several involved comparisons among programs. Based on their review, the authors concluded that alternative programs had been shown to produce competent teachers, at least under certain circumstances. However, the small number of studies raised concern about the findings being representative of all alternative route programs, the vast majority of which had never been subjected to professional scrutiny. The authors also noted certain commonalities among the 10 studies and attributed their success to (a) meaningful collaboration between teacher preparation programs and school districts, (b) adequate length and program coherence, and (c) shared responsibility for supervision and mentoring. Two of the studies they reviewed (Nougaret et al., 2005; Sindelar et al., 2004) met the inclusion criteria for this review.

Sindelar et al. (2004) compared graduates of six alternative models and four traditional programs on classroom performance (on Praxis III), and self and principals' ratings of preparedness. The six alternative programs were organized into two groups by sponsorship: Three were offered by districts and three by districts working in collaboration with universities. Forty-six 1st-year teachers were observed in their classrooms, and larger samples of graduates and their principals were asked to complete surveys that included scales of preparedness linked to Praxis criteria.

Sindelar et al. (2004) reported that although graduates from all 10 programs met the minimum Praxis III standard for beginning teacher competence, differences among the groups were observed. Graduates of traditional programs were rated significantly higher than graduates of alternative 
programs on several criteria, primarily in the teaching for student learning domain. On (a) making goals and procedures clear, (b) making content comprehensible, and (c) monitoring and providing feedback, traditional program graduates scored significantly higher than graduates of both alternative routes. However, on several other criteriabecoming familiar with students, promoting fairness, communicating with parents - differences were observed between the two alternative models, such that ratings of graduates from the traditional and collaborative programs were significantly higher than ratings of graduates from the district-only programs. On yet another criterion, building professional relationships, graduates from collaborative programs were rated significantly higher than graduates of either traditional or district-only programs.

By contrast, on self-ratings of preparedness, there were no significant differences by program type on any of the criteria. On the majority of principals' ratings of preparedness, however, alternative route completers were rated higher (and collaborative program completers were rated significantly higher) than graduates of traditional programs. Sindelar et al. (2004) attributed the striking differences between principals' ratings of preparedness and observers' judgments of classroom practice to the fact that Praxis III taps formal knowledge for teaching, whereas principals' ratings are more likely to be based upon teachers' skill in working within the school environment. Indeed, completers of both alternative routes were teachers and paraprofessionals who had experience in schools and who knew more about how to operate effectively within a school context than recent graduates working in schools for the first time.

The findings from this and other recent studies (Rosenberg, Boyer, Sindelar, \& Misra, 2007; Sindelar, Dewey, Rosenberg, Corbett, Denslow, \& Lotfinia, in press) suggest that the distinction between traditional and alternative programs is not a particularly useful one in special education. The vast majority of programs in both studies were not streamlined in the NCLB sense (a point not lost on proponents; Walsh \& Jacobs, 2007). In both studies, colleges and universities offered most alternative routes, and these programs tended to be as extensive as on-campus programs. Thus, in lieu of traditional/alternative comparisons, extensive versus streamlined has emerged as a critical dimension for differentiating programs in a potentially meaningful way.

Three special education studies (Boe et al., 2007; Feng \& Sass, 2010; Nougaret et al., 2005) bear directly on the extensiveness question. Nougaret et al. (2005) compared the classroom performance of 20 traditionally prepared novice teachers to 20 novices who had completed no more than six credits toward licensure. Each teacher was observed twice using the Danielson (1996) framework, an adaptation of Praxis III. Nougaret et al. found that traditionally trained teachers were rated substantially and significantly higher than the untrained teachers on the three observed domains (planning and preparation, classroom environment, and instruction). In fact, the mean effect size for preservice preparation was roughly 1.6 standard deviations; thus, the average teacher in the traditional training group was rated the same as a teacher in the 90th percentile of the untrained group. By contrast, on self-assessments, the two groups of teachers did not differ in any domain.

Boe et al. (2007) analyzed SASS data to assess the relationship between extensiveness of preparation, on the one hand, and professional qualifications and sense of preparedness, on the other. SASS is a survey of nationally representative samples of schools and teachers conducted periodically by the U.S. Department of Education. Among the many questions on the survey, five address initial preparation. Boe and his colleagues differentiated between extensive, some, and no training based on responses to these questions. They found that nearly $85 \%$ of special and general education novice teachers had extensive preparation and, not surprisingly, that novice teachers with extensive training were more likely than novice teachers with some or no training to be fully certified for the positions they held. Novice teachers with extensive preparation were also more likely to report feeling better prepared in subject matter and pedagogy. Of course, in defining extensiveness of preparation, Boe et al. were limited to the five SASS questions that address initial preparation. Thus, in this study, extensive training involved at least 5 weeks of practice teaching and completion of four components of teacher preparation - a course in selecting and adapting instructional materials, a course in educational psychology, opportunities to observe others teaching, and feedback on one's teaching.

Feng and Sass (2011) also conducted an analysis of a large-scale database (the Florida Data Warehouse) that allowed them to link teachers and students and to use student achievement gain as a dependent measure in evaluating the impact of preparation. By virtue of having used student achievement gain as a criterion, their study is regarded as an important step forward. Feng and Sass found that achievement gains in special education reading courses were greater when instructors were fully certified and had completed preservice preparation in special education. For a subsample of teachers, college transcripts were also available in the data set. For this subset, Feng and Sass found that the relationship between hours of special education courses and reading achievement gains was roughly twice as large as the effect when measured by certification.

\section{Unified Preparation Programs}

With the rise of inclusive classroom settings, all teachers must be prepared to serve students with a wide range of 
abilities and backgrounds. One solution to these broadening demands is unified teacher preparation. Although unified programming can vary in content, sequence, and outcomes, unified teacher preparation programs foster collaboration among university faculty and students in general and special education (Winn \& Blanton, 1997) and typically provide coursework and field experience addressing students with disabilities. Utley (2009) highlighted one such program comprised of a common course sequence for preservice teachers in elementary, secondary, and special education preparation programs that sought to provide teaching and intervention strategies for inclusive settings. Preservice teachers spent a semester learning principles of instruction and assessment with attention to meeting the needs of students with disabilities. In the second semester, they applied what they learned to the design and implementation of a unit of study. Utley analyzed a unit of study for each teacher in addition to the teacher's lesson plans, with special attention paid to how instruction was executed and differentiated to meet the needs of all learners in the classroom. Based on student pre- and postunit growth data, Utley reported that 14 of 20 teachers demonstrated learning gains within the range of typically developing classmates in all of their students with disabilities, and, of those preservice teachers who produced gains for students with disabilities, cooperative learning was the most frequently employed strategy.

Van Laarhoven et al. (2007) described what they called an enhanced preparation model. The enhanced model was a voluntary project for elementary, secondary, and special education preservice teachers consisting of enrollment in a 10-hour institute prior to the start of the semester; enrollment during the semester in a special section of a course about collaborative teaching in inclusive settings; participation in fieldwork experience in an inclusive setting; and extra instruction in FBA, instructional accommodations, and assistive technology.

To evaluate the project, Van Laarhoven et al. (2007) compared project participants with a control group of preservice teachers not participating in the project. Unlike project participants, students in the standard program had no clinical experience in inclusive settings and no formal interaction with special education majors. On pre- and postsurveys and responses to vignettes, participants in the enhanced program had higher content knowledge and more positive attitudes about inclusion than students in the control group. Although there was a significant difference in knowledge between general education and special education preservice teachers on presurveys, there was no significant difference at the end of the enhanced program. This study supports the idea that interdisciplinary collaboration can yield meaningful growth and change, particularly for general education preservice teachers, but exactly how changes are supported by specific program components is less well understood.
Three studies examined the benefit of unified preparation models specifically for early childhood teacher preparation (Dunne, 2002; LaMontagne et al., 2002; Miller \& Losardo, 2002). Dunne (2002) sought to understand the differences between unified early childhood and programs offering separate early childhood (EC) and early childhood special education (ECSE) programs. She administered surveys to and conducted follow-up interviews with faculty, program coordinators, and students no more than 1 year past graduation from 23 programs across the country. Dunne asked about course content, field placements, and program administration (including required courses); the nature of faculty interactions; and the rationale underlying the unified or separate approach to preparation. Students also were asked whether their certification would be unified or separate. Then, students and faculty in four different programs (two unified and two separate) participated in semistructured follow-up interviews in which they reflected on their experiences and knowledge related to their teacher preparation program.

Students enrolled in unified and ECSE programs received more coursework on normal and atypical child development than students in ECE programs. Unified programs also required more coursework focusing on collaboration across disciplines. Ultimately, students in ECSE and unified programs reported feeling more prepared to work with all children. Faculty and program coordinators reported that students enrolled in ECSE and unified programs were more likely to be placed in inclusive settings, whereas most students in ECE programs did not have any requirements or opportunities to work with children with disabilities. In unified programs, faculty collaborated frequently, whereas faculty in schools offering separate programs rarely if ever collaborated.

Similarly, LaMontagne et al. (2002) sought to examine the variation in experience and knowledge of preservice teachers enrolled in unified, ECE, and ECSE programs. They conducted two different studies. The first used faculty interviews to gain an understanding of unified program development. The second examined the perceptions of students in unified, dual, or separate ECE and ECSE preparation programs. ECE and ECSE standards were randomly mixed on a questionnaire. Graduates from master's level programs that were unified, dual certification, or separate ECE or ECSE were asked to rate their knowledge of each standard using a 5-point Likert scale. Consistent with findings from the faculty interviews and the results of Dunne (2002), graduates of ECSE programs reported stronger knowledge when it came to standards related to collaboration with colleagues across disciplines. While ECE graduates reported having a strong knowledge base in relation to ECE standards, they lacked competence in ECSE standards.

Finally, Miller and Losardo (2002) surveyed graduates of a unified program during their 1st year of employment after 
graduation. Their survey explored current employment, perception of strengths and weaknesses of their program, and recommendations for change. Overall, participants felt that they still had greater strengths and knowledge specific to general child development and ECE as opposed to ECSE. Although they reported feeling prepared to work with diverse families, participants suggested that increasing content on and fieldwork with students with disabilities could strengthen the program.

\section{Distance Education}

Fast-paced technological advances in the past 10 years have made new approaches to preservice teacher education possible. One important and widespread way that technology is being folded into teacher education programs is distance education, which has several potential benefits, including providing opportunities for nontraditional students and students from rural areas to complete coursework off campus. These benefits are particularly appealing to special education teacher educators who often feel pressured to address special education's long-standing personnel shortage by increasing preservice teacher enrollments.

Several studies compared outcomes in traditional face-toface instructional formats versus courses that were taught using online components. Beattie, Spooner, Jordan, Algozzine, and Spooner (2002) found that preservice teachers' course evaluations of a methods course in learning disabilities were similar whether presented in online or face-to-face formats. In addition to measuring preservice teachers' perceptions about distance education, several research teams (Caywood \& Duckett, 2003; Pindiprolou, Peck Peterson, Rule, \& Lignugaris-Kraft, 2003; Smith, Smith, \& Boone, 2000) have investigated knowledge acquisition and application outcomes. Smith, Smith, and Boone (2000) found that preservice teachers enrolled in an educational technology integration course performed equally well on pre- and posttest knowledge measures in online and traditional class formats that made use of lectures, guided instruction, and collaborative discussions. Finally, one study examined the effects of distance education learning for a course in behavior management. Caywood and Duckett (2003) evaluated students' knowledge acquisition and application in a student teaching experience and found no significant differences between students who took the course in a traditional format and those who took the course online.

Pindiprolou et al. (2003) investigated how various online pedagogies differed. They evaluated students' knowledge acquisition and application in an applied behavior analysis course that made use of case-based instruction. Students worked on cases either (a) independently and asynchronously, (b) independently with the support of an instructor, or (c) collaboratively. Students were evaluated pre- and posttest using declarative knowledge and application measures of FBAs. Students' declarative knowledge was measured using a multiple-choice paper-pencil test, while application knowledge was measured by having students answer questions about video-based cases. The three online formats were equally effective in facilitating students' application of functional behavioral assessment skills.

\section{Summary on Effective Program Types}

In terms of the quality of classroom instruction, sense of preparedness, the probability of in-field assignment, and impact on achievement growth in reading, extensive preparation (as opposed to streamlined) in special education makes a discernible and positive difference. The studies we reviewed also provide promising findings in support of unified preparation. Results indicate that unified programming fostered interdisciplinary collaboration among preservice teachers and faculty and also provided opportunities for coursework and fieldwork with students with disabilities. In addition, in these studies, unified programs showed some promise for improving preservice teachers' ability to include students with mild disabilities successfully, although, in early childhood unified programs, graduates perceived needing more information about students with severe disabilities. This latter finding is important because students in all programs are qualified to work with students with both mild and severe disabilities (Dunne, 2002; LaMontagne et al., 2002; Miller \& Losardo, 2002). Additionally, we do not know how specific aspects of the program assisted preservice teachers in developing more accessible and effective content instruction.

Taken together, findings on distance education are positive, although they should be interpreted conservatively as few of the studies included an assessment of statistical power. Findings indicate that courses taught online seem to be equally effective in facilitating preservice teachers' learning about course content and, in a few studies, their application of course content in practical situations. Moreover, the Pindiprolou et al. (2003) study provides initial evidence that within distance education multiple strategies can be used to support preservice teacher learning, and some of these strategies might be more effective than others. All of the studies we reviewed examined distance education in the context of one stand-alone course, and pedagogical strategies used in each course were not necessarily complementary. At this point, we have no understanding of effective distance education pedagogies or how distance education can be used to support an entire program or what the effects of this scaling up would be.

\section{CONCLUSIONS}

Based on findings from our review and a previous review conducted by Sindelar et al. (2006), it appears that special 
education teacher educators and researchers are beginning to implement practices and pursue lines of research that will facilitate preservice teachers' development of expertise. Features that are emerging as effective and therefore should be considered when crafting special education preservice teacher education programs include the following:

1. Coursework that blends content knowledge (particularly in reading and mathematics) with procedural or pedagogical knowledge

2. Pedagogies that promote active learning (i.e., casebased instruction, video modeling, tutoring experiences)

3. Coursework aligned with high-quality field experiences

4. Opportunities for special education and general education preservice teachers to collaborate

5. Extended, rather than abbreviated, opportunities to learn to teach

Pedagogies that promote active learning, such as case-based instruction and video modeling seemed helpful in promoting preservice teachers' acquisition of essential knowledge about content, disability, diversity, and instructional practice; and these pedagogies seem to promote knowledge application, at least in limited ways (e.g., teachers can recall the steps of a strategy). More research demonstrating how preservice teachers apply the knowledge in fieldwork and classrooms as beginning teachers is needed.

Although research is clear on the important role that teachers' beliefs play in how they approach teaching and learning, results from our review suggest that how to address beliefs in ways that have an impact on practice is less clear. Our research showed that when coursework incorporated active learning strategies, such as video modeling, reflection, discussion, and journaling, preservice teachers' understandings of diversity and attitudes toward disability improved, at least as assessed using concept maps and surveys. However, the long-term impact of these strategies or sets of strategies on classroom practice deserves further attention. Daunic et al. (2004) found no differences between preservice special and general education teachers who had access to more coursework and field experience with culturally and linguistically diverse students and those without such preparation. By contrast, VanLaarhoven et al. (2008) demonstrated the impact of well-structured coursework and field experiences focused on the inclusion of students with disabilities. Their enhanced program improved the attitudes of both general and special education preservice teachers towards inclusion and toward the use of specific instructional practices compared to their peers who did not have such experiences.
Finally, the use of self-efficacy measures warrants more careful consideration. It seems that group differences disappear or are difficult to detect when using such measures. We suspect several possible explanations for this phenomenon including (a) measures that may not be sensitive enough to measure subtle changes in teachers' self-efficacy, (b) preservice teachers not having enough time in classrooms to develop a strong sense of self-efficacy, or (c) influencing constructs like self-efficacy and beliefs is difficult, especially over short periods of time.

The research findings we examined emphasized the importance of aligning coursework and field experiences. In some studies, coursework and field experiences emphasized more universally applicable strategies; others emphasized content-specific knowledge and practices. In both cases, however, special education and general education preservice teachers who had access to carefully structured and well-aligned learning experiences grew in their knowledge and instructional practice. Further, when preservice teachers had access to well-aligned and structured experiences in reading and mathematics, they demonstrated the ability to improve the achievement of students with disabilities and struggling learners. It seems important that teacher educators in special education and unified preparation programs find ways to align coursework and field experiences. If they want preservice teachers to develop the applied knowledge they need for teaching students with disabilities, particularly in key content areas, they must also be mindful of how pedagogical content knowledge is incorporated into those experiences. Equally important is access to quality field experiences. This review provided some evidence about strategies for improving field experiences.

The structure of preservice programs also exerts an influence on the skills and knowledge of beginning special education teachers. Extensive preparation programs compared to shortened programs result in stronger classroom practice and improved student achievement in reading. Further, unified preparation seems to have a positive impact on teachers' knowledge and attitudes towards inclusion, with a primary key to such programs being the incorporation of field experiences in inclusion classrooms. Less clear, however, is how such collaborative program experiences promote the differentiated expertise of general and special educators (Brownell, Griffin, Leko, \& Stephens, 2011). Finally, the research we reviewed and the Sindelar et al. (2006) review suggest that using technology to deliver distance education is an effective vehicle for delivering coursework that focuses on both factual and applied knowledge. How technology can be used to improve pedagogical skills or field experiences completed at a distance has not been investigated widely. 


\section{IMPLICATIONS FOR THE FUTURE OF TEACHER EDUCATION}

The research literature on special education teacher preparation has grown substantially since previous reviews. Findings from a small number of studies provide support for practices identified as potentially effective in earlier reviews and provide some support for additional practices; however, there is much work to be done. We need more studies of the individual strategies explicated in this review and previous reviews and studies in which interventions are framed within some well-articulated view or theory of how beginning special education teacher knowledge and skill is acquired.

We also need to understand more about the long-term impact of well-aligned and carefully structured coursework and field experiences and how they can be integrated into special education and unified preparation. Will preservice teachers who demonstrate positive gains in knowledge and classroom practice and demonstrate gains in student achievement as a result of such coursework and field experiences continue to draw on their knowledge when they enter the classroom as beginning teachers? Attempts to create such linkages between coursework and field experiences, particularly when they are embedded in content areas, will necessitate that teacher education programs focus more deliberately on a smaller number of concepts and strategies. Achieving such a tight focus on intervention within the content areas seems imperative if future special education teachers are to play an important role in a Response to Intervention (RTI) framework; however, doing so will present some substantial challenges. Presently, special education teachers play multiple roles in schools, and, as a consequence, certification and licensure requirements are conceived broadly (e.g., K-12 mild to moderate certification). How can teacher educators focus their efforts when special educators must be prepared broadly to fill so many different roles? Yet, what would be the consequences of not preparing special education teachers to provide interventions in a RTI framework? Would special education teachers become obsolete?

Crafting well-aligned coursework and fieldwork of course also depends on high-quality field experiences, where cooperating teachers are modeling the universally designed instruction and effective interventions in reading, mathematics, and writing that students are learning about in their courses. The strategies mentioned in this paper for improving the quality of preservice teachers' applied experiences, such as training cooperating teachers to use teaching artifacts with special education teachers, are potentially productive, yet such practices are not widespread and therefore are unlikely to dramatically improve the quality of field experiences available to preservice teachers on a wide scale. Advances in the use of technology to train other professionals, however, hold great promise for helping preservice teachers develop applied knowledge. Teacher educators need to consider how web-based technologies, such as BIE coaching, video modeling, and virtual technology can be used to help preservice special education teachers gain access to the applied knowledge they need. The virtual classroom, developed by researchers at the University of Central Florida to improve preservice teachers' ability to address the needs of urban students during classroom instruction, is a high-quality exemplar of what might happen to improve field experiences dramatically.

Attempts to improve the quality of coursework and field experiences in preservice special education and unified preparation seem at odds with increasing use of streamlined preparation programs, like Teach for America and the New Teacher Project. How can teacher educators position themselves to secure the resources they need to improve and study teacher education when an ever-increasing amount of private foundation and federal monies are being channeled into these politically popular preparation programs? Additionally, how can colleges of education convince bright young persons to enroll in their programs when such quick routes are available to them?

Our final thoughts turn to the assessment of special education teacher education efforts. We need more precise and valid instruments to measure aspects of beginning teacher competence and its application in classrooms. There has been and continues to be a push for teacher education to be linked to student outcomes as a way of justifying its existence, but there are problems with using student outcomes as a means for designing and improving teacher preparation programs. Student outcomes are distal measures of the effectiveness of teacher education, ones that are influenced considerably by special education teachers' school and classroom context. Distal measures tell us little about what competent novices should know about teaching and what they should be able to do in classrooms upon graduation. Yet, evaluating teacher preparation on the basis of the achievement gains graduates produce in their classrooms has gained political traction. As a result, teacher educators are uncertain about what they should be aiming for in teacher education programs and how to demonstrate persuasively that they have accomplished their aims. Focusing instead on crafting instruments that measure more precisely what special education teachers need to know and do to become competent is a more informative and practical way to focus our efforts in teacher education.

\section{REFERENCES}

Alexander, M., Lignugaris-Kraft, B., \& Forbush, D. (2007). Online mathematics methods course evaluation: Student outcomes, generalization, and pupil performance. Teacher Education and Special Education, 30, 199-216. doi:10.1177/088840640703000303 
Allinder, R. M. (2001). Effects of modeling on attitudes and perceptions of preservice special education teachers. Teacher Education and Special Education, 24, 362-372. doi:10.1177/0888406401024 00410

Al Otaiba, S., Schatschneider, C., \& Silverman, E. (2005). Tutorassisted intensive learning strategies in kindergarten: How much is enough? Exceptionality, 13, 195-208. doi:10.1207/s15327035ex 1304_2

Beattie, J., Spooner, F., Jordan, L., Algozzine, B., \& Spooner, M. (2002). Evaluating instruction in distance learning classes. Teacher Education and Special Education, 25, 124-132. doi:10. $1177 / 088840640202500204$

Bishop, A. G., Brownell, M. T., Klingner, J. K., Leko, M. M., \& Galman, S. A. C. (2010). Differences in beginning special education teachers: The influence of personal attributes, preparation, and school environment on classroom reading practices. Learning Disabilities Quarterly, 33, 75-92.

Boe, E., Cook, L. \& Sunderland, R. (2008). Teacher turnover: Examining exit attrition, teaching area transfer, and school migration. Exceptional Children, 75, 7-31.

Boe, E. E., Shin, S., \& Cook, L. H. (2007). Does teacher preparation matter for beginning teachers in either special or general education? Journal of Special Education, 41, 158-170. doi:10.1177/ 00224669070410030201

Bradley, J. F., \& Monda-Amaya, L. E. (2005). Conflict resolution: preparing preservice special educators to work in collaborative settings. Teacher Education and Special Education, 28, 171-184. doi: 10.1177/088840640502800404

Brownell, M. T., Bishop, A. G., Gersten, R., Klinger, J. K., Penfield, R. D., Dimino, J., ... Sindelar, P. T. (2009). The role of domain expertise in beginning special education teacher quality. Exceptional Children, 75, 391-411.

Brownell, M. T., Griffin, C., Leko, M. M., \& Stephens, J. (2011). Improving collaborative teacher education research: Creating tighter linkages. Teacher Education and Special Education, 34 , 235-239. doi:10.1177/0888406411404570

Brownell, M. T., Haager, D., Bishop, A. G., Klingner, J. K., Menon, S., Penfieid, R., \& Dingle, M. (2007, April). Teacher equality in special education: The role of knowledge, classroom practice, and school environment. Paper presented at the annual meeting for American Education Research Association, Chicago, Illinois.

Brownell, M. T., Sindelar, P. T., Kiely, M. T., \& Danielson, L. C. (2010). Special education teacher quality and preparation: Exposing foundations, constructing a new model. Exceptional Children, 76, 357-377.

Carlson, E., Lee, H., \& Schroll, K. (2004). Identifying attributes of high quality special education teachers. Teacher Education and Special Education, 27, 350-359. doi: 10.1177/08884064040270 0403

Caywood, K., \& Duckett, J. (2003). Online vs. on-campus learning in teacher education. Teacher Education and Special Education, 26, 98-105. doi:10.1177/088840640302600203

Correa, V. I., Hudson, R. F., \& Hayes, M. T. (2004). Preparing early childhood special educators to serve culturally and linguistically diverse children and families: Can a multicultural education course make a difference? Teacher Education and Special Education, 27, 323-341. doi:10.1177/088840640402700401

Danielson, C. (1996). Enhancing professional practice: A framework for teaching. Alexandria, VA: Association for Supervision and Curriculum Development.
Daunic, A. P., Correa, V. I., \& Reyes-Blanes, M. E. (2004). Teacher preparation for culturally diverse classrooms: Performance-based assessment of beginning teachers. Teacher Education and Special Education, 27, 105-118. doi:10.1177/088840640402700203

Dieker, L. A., Lane, H. B., Allsopp, D. H., O’Brien, C., Wright, T., Kyger, M., ... \& Fenty, N. (2009). Evaluating video models of evidence-based instructional practices to enhance teacher learning. Teacher Education and Special Education, 32, 180-196. doi: $10.1177 / 0888406409334202$

Dotger, B. \& Ashby, C. (2010). Exposing conditional inclusive ideologies through simulated interactions. Teacher Education and Special Education, 33, 114-130. doi:10.1177/0888406409357541

Dunne, L. F. (2002). Characteristics of unified and separate early childhood education and early childhood special education programs: A national study. Teacher Education and Special Education, 25, 219-235. doi:10.1177/088840640202500303

Elksnin, L. K. (1998). Use of the case method of instruction in special education teacher preparation programs: A preliminary investigation. Teacher Education and Special Education, 21, 95-108. doi:10.1177/088840649802100204

Feng, L., \& Sass, T. R. (2011). Special education teacher quality and student achievement. Manuscript submitted for publication.

Gettinger, M., Stoiber, K., \& Koscik, R. (2008). Effects of a preparation program focused on accommodating children with challenging behaviors. Teacher Education and Special Education, 31, 164-181. doi: 10.1177/0888406408330624

Gormley, S., \& Ruhl, K. L. (2007). Language structure knowledge of preservice teachers: Connecting speech to print. Teacher Education and Special Education, 30, 83-92. doi: 10.1177/08884064070 3000203

Griffin, C. C., Jitendra, A. K., \& League, M. B. (2009). Novice special educators' instructional practices, communication patterns, and content knowledge for teaching mathematics. Teacher Education and Special Education, 32, 319-336. doi:10.1177/088840640934 3540

Hess, F. M. (2001). Tear down the wall: The case for a radical overhaul of teacher certification. Washington, DC: Progressive Policy Institute. Retrieved from http://www.ppionline.org/ppi_sub.cfm? knlgAreaID $=110 \&$ subsec $I D=135$

Kamens, M. W. (2007). Learning about co-teaching: A collaborative student teaching experience for preservice teachers. Teacher Education and Special Education, 30, 155-166. doi: 10.1177/ 088840640703000304

Kim, O., Utke, B. J., \& Hupp, S. C. (2005). Comparing the use of case studies and application questions in preparing special education professionals. Teacher Education and Special Education, 28, 104-113. doi: 10.1177/088840640502800204

LaMontagne, M. J., Johnson, L. J., Kilgo, J. L., Stayton, V., Carr, V., Bauer, A. M., \& Carpenter, J. (2002). Unified early childhood personnel preparation programs: perceptions from the field. Teacher Education and Special Education, 25, 236-246. doi:10.1177/08 8840640202500304

Leko, M. M., \& Brownell, M. T. (2011). Special education preservice teachers' appropriation of pedagogical tools for teaching reading. Exceptional Children, 77, 229-251.

Maheady, L., Jabot, M., Rey, J., \& Michielli-Pendl, J. (2007). An early field-based experience and its impact on pre-service candidates' teaching practice and their pupils' outcomes. Teacher Education and Special Education, 30, 24-33. doi:10.1177/08884064070300 0103 


\section{FOCUSO Exceptional children}

Miller, P. S., \& Losardo, A. (2002). Graduates' perceptions of strengths and needs in interdisciplinary teacher preparation for early childhood education: A state study. Teacher Education and Special Education, 25, 309-319. doi:10.1177/088840640202500310

Mitchem, K., Koury, K., Hollingshead, C., Miller, K., Tsai, H., \& Zha, S. (2009). The effects of instructional implementation on learning with interactive multimedia case-based instruction. Teacher Education and Special Education, 32, 297-318. doi:10.1177/0888 406409343520

Moats, L. (2009). Knowledge foundations for teaching reading and spelling. Reading and Writing, 22, 379-399. doi: 10.1007/s11145009-9162-1

Nougaret, A. A., Scruggs, T. E., \& Mastropieri, M. A. (2005). Does teacher education produce better special education teachers? Exceptional Children, 71, 217-229.

Parker-Katz, M., \& Hughes, M. T. (2008). Preparing special education mentors using classroom artifacts as a vehicle for learning about teaching. Teacher Education and Special Education, 31, 268-282. doi: $10.1177 / 0888406408330646$

Paulsen, K. J. (2005). Infusing evidence-based practices into the special education preparation curriculum. Teacher Education and Special Education, 28, 21-28. doi: 10.1177/088840640502800103

Pindiprolu, S. S., Peck Peterson, S. M., Rule, S., \& Lignugaris-Kraft, B. (2003). Using web-mediated experiential case-based instruction to teach functional behavioral assessment skills. Teacher Education and Special Education, 26, 1-16. doi: 10.1177/08884064 0302600102

Richards, S. B., Hunley, S., Weaver, R., \& Landers, M. F. (2003). A proposed model for teaching collaboration skills to general and special education preservice candidates. Teacher Education and Special Education, 26, 246-250. doi:10.1177/08884064030260 0311

Rock, M. L., Gregg, M., Thead, B. K., Acker, S. E., Gable, R. A., \& Zigmond, N. P. (2009). Can you hear me now? Evaluation of an online wireless technology to provide real-time feedback to special education teachers-in-training. Teacher Education and Special Education, 32, 64-82. doi:10.1177/0888406408330872

Rosenberg, M. S., Boyer, K. L., Sindelar, P. T., \& Misra, S. (2007). Alternative route programs to certification in special education: What we know about program design, instructional delivery, and participant characteristics. Exceptional Children, 73, 224-241.

Rosenberg, M. S., \& Sindelar, P. T. (2005) The proliferation of alternative routes to certification in special education: A critical review of the literature. Journal of Special Education, 39, 117-127. doi:10.1177/00224669050390020201

Scheeler, M. C., \& Lee, D. L. (2002). Using technology to deliver immediate corrective feedback to teachers. Journal of Behavioral Education, 11, 231-241. doi:10.1023/A:1021158805714

Scheeler, M. C., McAfee, J. K., Ruhl, K. L., \& Lee, D. L. (2006). Effects of corrective feedback delivered via wireless technology on preservice teacher performance and student behavior. Teacher Education and Special Education, 29, 12-25. doi:10.1177/0888 40640602900103

Sears, S., Cavallaro, C., \& Hall, S. (2004). Quality early field experiences for undergraduates. Teacher Education and Special Education, 27, 75-79. doi:10.1177/088840640402700108

Seo, S., Brownell, M. T., Bishop, A. G., \& Dingle, M. (2008). Beginning special education teachers' classroom reading instruction: Practices that engage elementary students with learning disabilities. Exceptional Children, 75, 97-122.
Sindelar, P. T., Bishop, A. G., \& Brownell, M. T. (2006). What's special about special education? Research on the preparation of special education teachers. In B. G. Cook \& B. R. Schirmer (Eds.), What is special about special education: Examining the role of evidence-based practices (pp. 113-126). Austin, TX: Pro-Ed.

Sindelar, P. T., Daunic, A., \& Rennells, M. S. (2004). Comparisons of traditionally and alternatively trained teachers. Exceptionality, 12, 209-223. doi:10.1207/s15327035ex1204 3

Sindelar, P. T., Dewey, J. F., Rosenberg, M. S., Corbett, N. L., Denslow, D., \& Lotfinia, B. (in press). Cost effectiveness of alternative route special education teacher preparation. Exceptional Children.

Smith, S. B., Smith, S. J., \& Boone, R. (2000). Increasing access to teacher preparation: The effectiveness of traditional instructional methods in an online learning environment. Journal of Special Education Technology, 15, 37-46.

Spear-Swerling, L., (2009). A literacy tutoring experience for prospective special educators and struggling second graders. Journal of Learning Disabilities, 42, 431-443. doi:10.1177/002221940933 8738

Spear-Swerling, L., \& Brucker, P. O. (2004). Preparing novice teachers to develop basic reading and spelling skills in children. Annals of Dyslexia, 54, 332-364. doi:10.1007/s11881-004-0016-x

Stough, L. M., \& Palmer, D. J. (2003). Special thinking in special settings: A qualitative study of expert special educators. The Journal of Special Education, 36, 206-222. doi:10.1177/00224669030360 0402

Trent, S. C., \& Dixon, D. J. (2004). "My eyes were opened": Tracing the conceptual change of pre-service teachers in a special education/multicultural course. Teacher Education and Special Education, 27, 119-133. doi:10.1177/088840640402700204

Tulbert, B., Sindelar, P. T., Correa, V. I., \& La Porte, M. M. (1996). Looking in the rear view mirror: A content analysis of teacher education and special education. Teacher Education and Special Education, 19, 248-261.

Utley, B. L. (2009). An analysis of the outcomes of a unified teacher preparation program. Teacher Education and Special Education, 32, 137-149. doi:10.1177/0888406409334204

Van Laarhoven, T. R., Munk, D. D., Lynch, K., Bosma, J., \& Rouse, J. (2007). A model for preparing special and general education preservice teachers for inclusive education. Journal of Teacher Education, 58, 440-455. doi:10.1177/0022487107306803

Van Laarhoven, T., Munk, D. D., Zurita, L. M., Lynch, K., Zurita, B., Smith, T., \& Chandler, L. (2008). The effectiveness of video tutorials for teaching preservice educators to use assistive technologies. Journal of Special Education Technology, 23, 31-45.

Walsh, K. (2001). Teacher certification reconsidered: Stumbling for quality. Baltimore: Abell Foundation. Retrieved from http://www. abell.org/publications/detail.asp?ID $=59$

Walsh, K., \& Jacobs, S. (2007, September). Alternative certification isn't alternative. Washington, DC: Fordham Institute. Retrieved from http://www.nctq.org/p/tqb/docs/Alternative_Certification_Is nt_Alternative_20071113021230.pdf

Winn, J. W., \& Blanton, L. (1997). The call for collaboration in teacher education. In L. P Blanton, C. C. Griffin, J. A. Winn, \& M. C. Pugach (Eds.), Teacher education in transition (pp. 1-17). Denver, CO: Love. 